\title{
São Paulo e a Ideologia Higienista entre os séculos XIX e XX: a utopia da civilidade ${ }^{1}$
}

\section{Resumo}

No contexto da modernidade, situamos o período entre o final do Século XIX e início do XX, em São Paulo, mais precisamente nos primórdios da República, quando houve um processo de higiene e limpeza social, associado à pobreza e, ao mesmo tempo, a um desejo utópico de uma cidade limpa e saudável, como ideologia elitista.

Palavras-chave: Higiene. Utopia. Pobreza. Ideologias. Civilidade.

Hygienism in Sao Paulo between 19th and 20th centuries: the civilizing utopia

\section{Abstract}

In this paper, we analyze, within the context of modernity, the period between the end of the $19^{\text {th }}$ century and the beginning of the $20^{\text {th }}$ century in São

\footnotetext{
${ }^{1}$ Artigo elaborado a partir do Capítulo I de minha Dissertação de Mestrado em Políticas Sociais pela Universidade Cruzeiro do Sul-UNICSUL, intitulada "A Concepção saneadora da pobreza nas políticas públicas contemporâneas (2006-2011) na Cidade de São Paulo: análise crítica do processo de disciplinamento da informalidade" (2011).

*Mestre em Políticas Sociais pelo Programa de Pós-Graduação em Políticas Sociais da Universidade Cruzeiro do Sul. (Brasil) E-mail: affonsosobrinho@yahoo.com.br
} 
Paulo. More precisely, the early days of the Republic, when a process of hygiene and 'social cleansing' took place, which was associated with poverty, and, at the same time, with a utopian desire for a clean and healthy city as an ideology of elites.

Keywords: Hygiene. Utopia. Poverty. Ideology. Civility.

\section{As medidas higienistas-disciplinadoras dos espaços nos primórdios da república em São Paulo}

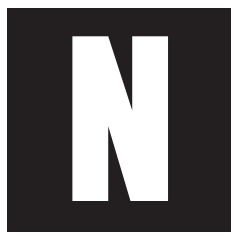

o espaço da desordem relacionado ao atraso dos trópicos em oposição à civilização² ${ }^{2}$, prevalecem as precárias condições de vida dos mais pobres no ambiente urbano. Uma das dificuldades a serem enfrentadas pelas elites $^{3}$ é tratar problemas que estas mesmas chamam de "ociosidade" e "vícios" e que, a partir de sua visão de mundo e de seus interesses, representam uma ameaça ao corpo social.

\footnotetext{
${ }^{2}$ De certo modo, o novo sentido de civilização, a partir do final do S18, é uma combinação específica das ideias de um processo e de uma condição adquirida. Tem atrás de si o espírito geral do iluminismo, com sua ênfase no autodesenvolvimento humano secular e progressivo. Civilização expressou esse sentido de processo histórico, mas também de refinamento e ordem [...] (Willians, 2007, p. 83).

${ }^{3}$ Elite, desde meados do Séc. 18, porém mais comumente desde princípios do Séc. 19, expressava principalmente uma distinção social por meio da posição, mas também podia ser utilizada para referir-se a distinções no interior de um grupo [...].

Não surpreende, portanto, que seu surgimento em um sentido moderno mais específico esteja relacionado aos debates conscientes sobre classe. Isso tem dois aspectos principais: o primeiro, o sentido de que houve uma ruptura nos velhos modos de distinguir pela oposição ou por hereditariedade aqueles mais aptos a governar ou exercer influência, e um fracasso na busca de novos modos de distinguir tais pessoas por meio de eleição formal (parlamentar ou democrática); segundo, em resposta aos argumentos socialistas sobre o governo de classes, ou sobre a política como conflito entre classes, o argumento de que as formações efetivas que governam e exercem influência não são as classes, mas as elites. O primeiro sentido, menos formal, está representado no S19 por muitas expressões alternativas - os letrados [clerisy] de Coleridge, os mais sábios [the wisest] de Mill, os melhores e os restantes [the Best e the remnant] de Arnold. A significação reside, em cada caso, na suposta distinção de tais agrupamentos em relação às poderosas formações sociais existentes. No uso geral do termo no S20, todos esses pressupos-
} 


\section{O SURGIMENTO DA IDEOLOGIA DA HIGIENE}

As classes pobres não passaram a ser vistas como classes perigosas apenas porque poderiam oferecer problemas para a organização do trabalho e a manutenção da ordem pública. Os pobres ofereciam também perigo de contágio. Por um lado, o próprio perigo social representado pelos pobres aparecia no imaginário político brasileiro de fins do século XIX através da metáfora da doença contagiosa: as classes perigosas continuaram a se reproduzir enquanto as crianças pobres permanecessem expostas aos vícios de seus pais. Assim, na própria discussão sobre a repressão à ociosidade, que temos citado, a estratégia de combate ao problema é geralmente apresentada como consistindo em duas etapas: mais imediatamente,

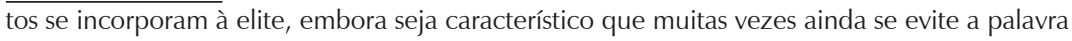
por causa de algumas de suas associações (hoje se usam mais frequentemente as noções abstratas de excelência ou de PADRÕES [v] para exprimir ideias similares ou relacionais). O segundo sentido, mais formal, introduz-se efetivamente em uma tendência da teoria social que deriva de Pareto e de Mosca (Willians, 2007, p. 150-151).

ELITE. Minoria influente que toma as decisões no interior de uma classe ou grupo social. Distinguem-se várias elites, abrangendo os membros dos grupos ocupacionais que possuem status elevado no conjunto da sociedade: a elite política, a elite intelectual, a elite empresarial e a elite militar estão entre as mais poderosas. O conceito de elite nas ciências políticas e sociais foi particularmente estudado pelos sociólogos italianos Vilfredo Pareto e Gaetano Mosca, no início do século XX. Para eles, a elite seria formada por indivíduos superiores, socialmente bem organizados. Ambos se preocuparam especificamente com a análise das elites políticas, controladoras do poder e donas de todas as vantagens proporcionadas pela função. Opunham-se, dessa forma, às teorias que centralizavam a análise política e social no mecanismo das classes sociais e no conflito existente entre elas. Atualmente, o estudo das elites relaciona-se com a complexidade das chamadas sociedades de massa, que abrigam poderosas organizações burocráticas (empresas oligopólicas, partidos políticos, sindicatos, meios de comunicação de massa e organizações estatais). Todas essas organizações seriam dominadas por elites específicas. O sociólogo Wright Mills, analisando a sociedade norte-americana em seu livro As Elites do Poder, distingue três elites fundamentais - dirigentes de empresas, líderes políticos e chefes militares —, todas basicamente recrutadas no interior do mesmo estrato social e unificadas em torno de objetivos comuns. Outros sociólogos norte-americanos distinguem cinco tipos de elite que habitualmente assumiram a liderança do processo econômico: elite dinástica, proveniente da aristocracia agrária (caso do Japão); elite de classe média, composta de membros de uma nova classe empresarial (Inglaterra e Estados Unidos); intelectuais revolucionários de tendência socialista (ex-União Soviética, China, Cuba); administradores coloniais, representantes do poder metropolitano nas colônias (África e Ásia); e líderes nacionalistas, recrutados no interior das camadas superiores ou nas Forças Armadas de países em desenvolvimento (Egito, Líbia) (Sandroni, 1999, p. 201). 
cabia reprimir os supostos hábitos de não-trabalho dos adultos; a mais longo prazo, era necessário cuidar da educação dos menores (Chalhoub, 2006, p. 29).

A cidade demanda uma intervenção da ordem e disciplina das condições de vida e do próprio trabalho por meio da higiene pública ${ }^{4}$. Utiliza-se dos discursos do progresso como uma utopia ${ }^{5}$ para que se possa disciplinar os espaços e corpos. Também a pobreza é associada às doenças causadas pela falta de higiene em moradias insalubres e aos odores exalados pelos ambientes propícios a propagações e manifestações perigosas de todo tipo, inclusive doenças contagiosas. Por isso, o estudo pela medicina será tão importante para compreender o corpo nos mínimos detalhes, para além da aparência. Geralmente, nesses ambientes, ocorre a degeneração do corpo físico e social. Um exemplo comum são os cortiços e as emanações de ratos, micróbios e contaminações perigosas do homem degenerado. Motivo de preocupação das elites e autoridades. Representa também uma ameaça à própria moralidade burguesa cristã da família, em especial os locais lasci-

\footnotetext{
${ }^{4}$ Higiene. Derivado do grego hygieinos (que tem saúde); tecnicamente é a parte da medicina que trata da saúde, mostrando os meios de conservá-la, evitando doenças.

A higiene pública, assim, compreende toda matéria de ordem propriamente sanitária, como toda medida de caráter mesmo policial, mas de interesse ou para fins higiênicos, isto é, de saúde pública.

A bem de saúde dos habitantes de um lugar e da salubridade dele, todas as medidas, aconseIhadas por esta parte da medicina, porém determinada pelo poder público, mesmo que, em certos casos, se mostrem restrições aos direitos individuais ou ao direito de propriedade (Silva, 1993, p. 383).

${ }^{5}$ Utopia 1. Termo criado por Tomás Morus em sua obra Utopia (1516), significando literalmente 'lugar nenhum' (Gr. ou: negação, topos: lugar), para designar uma ilha perfeita onde existiria uma sociedade imaginária na qual todos os cidadãos seriam iguais e viveriam em harmonia. A alegoria de Tomás Morus serviu de contraponto através do qual ele criticou a sociedade de sua época, formulando um ideal político-social inspirado nos princípios do humanismo renascentista.

2. Em um sentido mais amplo, designa todo projeto de uma sociedade ideal perfeita. O termo adquire um sentido pejorativo ao se considerar esse ideal como irrealizável e portanto fantasioso. Por outro lado, possui um sentido positivo quando se defende que esse ideal contém o germe do progresso social e da transformação da sociedade [...] (Japiassú; Marcondes, 2008, p. 274).
} 
vos e destruidores de lares, como os prostíbulos, geralmente localizados em áreas deterioradas da região central.

Os cortiços representam, portanto, uma ameaça à noção de civilidade; as greves, uma ameaça à ordem burguesa de cidade limpa, disciplinada e livre das imundícies e de manifestações turbulentas dos operários; a rua será objeto da disciplina devido à ameaça à própria ordem que mantém desigualdades. As doenças que se espalhavam pela urbe, do ponto de vista ideológico, teriam como foco de proliferação justamente as áreas pobres.

Nesse processo, a problemática da cidade foi delineada enquanto questão - a chamada questão urbana- encontrando-se atravessada pelos pressupostos da disciplina e da cidadania, passando a cidade a ser reconhecida como espaço de tensões. A primeira via a focalizar a cidade de São Paulo como uma 'questão' foi a higiênico-sanitarista, conjugando o olhar médico com a observação/transformação do engenheiro, junto a uma política de intervenção de um Estado planejador/reformador, que procurou de todas as formas neutralizar o espaço, dar-lhe uma qualidade universal e manipulável, mediante a 'racionalidade e objetividade' da ciência, que tem função-chave na sua luta contra o 'arcaico pela ordem e progresso', caminhando conjuntamente ao desejo já latente e generalizado de 'ser moderno', em que a cidade aparece como sinônimo de progresso em oposição ao campo. Conjuntamente à questão urbana, constrói-se a questão social com o surgimento da pobreza e a identificação do outro - o pobre, o imigrante.

A maior parte dos estudos que focalizam as transformações urbanas em São Paulo reproduz [...] o discurso característico das fontes oficiais- logo, públicas-, e mostra-se indicativa mais de um 'dever ser' do que de 'um ser', ao apresentar modelos de relações íntimas, procurando corrigir, extirpar, estigmatizar os comportamentos. [...] Esses estudos em geral reproduzem o privado como a imagem que dele tinha ou pretendia ter o público [...].

[...] A expansão urbana e capitalista do final do século XIX trouxe o aparecimento da noção de rentabilidade, eficácia 
do trabalho em todos os domínios, inclusive no espaço interior, destacando a importância da limpeza e da higiene para a saúde e bem-estar da família [...] (Matos, 1996, p.133).

O engenheiro e o médico, em especial o médico-sanitarista, aparecem como personagens de uma elite que propiciará as intervenções necessárias ao estabelecimento da nova ordem higienista; ações sanitárias serão desenvolvidas com vistas a combater epidemias, um ideal de limpeza e, ao mesmo tempo, desejo utópico do progresso.

Caldeira (2003) explica como se exercia um controle sobre a pobreza como sintoma de doença associada à desordem e à sujeira. É a partir das doenças que se identificam os desvios morais e os crimes como diagnóstico da elite no último quartel do século XIX.

Para combater doenças, foi criado o Serviço Sanitário para tratar as áreas propícias ao contágio, como no trecho a seguir:

\section{FEBRE AMARELA}

(EPIDEMIAS)

ERA ENDÊMICA no Rio de Janeiro. Em São Paulo, não havia endemia, mas no verão apareciam focos epidêmicos.

Era a moléstia 'do calor', da alimentação pesada e quente, feijoadas, cozidos, jacas, mangas, abacates, mas principalmente dos 'miasmas' (emanações pestilenciais de lagoas e focos de podridão).

Os higienistas e cientistas em São Paulo, Emílio Ribas, Adolfo Lutz, Vital Brasil, estavam ao corrente dos estudos dos norte-americanos em Havana.

Mas enquanto não se chegava a resultados positivos, era preciso agir.

Uma vez por semana, batiam à porta de cada casa homens do Desinfetório, que era dirigido por Diogo de Faria. Um trazia uma lata de 20 litros, cheia de desinfetante verde, de cheiro acre. Outro trazia uma espécie de pulverizador grande, que era fixado pelos pés do manipulador, e manejado como uma bomba de bicicleta. O terceiro um caderno de anotações com lápis amarrado, e usava terno comum, enquanto os demais vestiam roupa de zuarte azul. 
Havia gente que se indignava da constância e da meticulosidade dessas visitas domiciliares: 'Minha casa não é cortiço.' Mas, a polidez do moço do caderno vencia resistências. Só em casos raros e extremos a polícia interveio [...] (Americano, 2004, p. 414).

A concepção higienista é revelada ainda nas grandes construções, avenidas e bairros, que visam à importação de hábitos estrangeiros, como projetos de cidade, como os Campos Elíseos, Higienópolis e Bela Vista, que serão foco de atenção das elites e autoridades.

A estética burguesa será objeto de apreciação das camadas sociais variadas, os costumes parisienses serão difundidos pelas camadas privilegiadas como sinal de grandiosidade e bom gosto, em especial nas vestimentas e nas edificações. Um padrão de moralidade burguesa predomina, se aproxima mais do modo de vida europeu e renega o nacional como "atrasado socialmente". Será preciso manter a mente dos pobres distante dos vícios e pensamentos que degeneram o homem e educar as crianças pobres para o trabalho.

Portanto, para uma compreensão do modo como ocorreram as mudanças na paisagem e urbanização de São Paulo naquele momento, é importante a análise da questão social à luz do pensamento exógeno. Ou seja, reside nos hábitos e experiências estrangeiras a fonte de inspiração da nossa modernidade. E é assim que se fará o disciplinamento e tratamento da pobreza, num modelo de cidade que nega sua identidade, seu curso natural, sua beleza associada aos trópicos, e se privilegiam formas que escondem a realidade social. Esse processo se verifica na organização espacial da cidade, haja vista procurar-se, pelas construções, deixar os rios longe do alcance da visão, canalizando-os e encobrindo-os junto com o esgoto; além disso, aterram-se as áreas de várzea e alteram-se os contornos dos rios na região central. Portanto, foi uma importação mal feita de urbanização de fora. 


\section{O projeto urbanístico de Paris, suas contradições e confluências de utopias da modernidade}

É importante que se atente para o projeto urbanístico de Paris e a ideia de modernidade como espaço da modificação da paisagem urbana. Guardadas as devidas proporções de tempo e espaço histórico, esses aspectos trazem indícios para uma análise acerca do pensamento da nossa elite, que se inspirou nesse modelo de ideal de modernidade concebido fora e copiado para os trópicos: a negação dos pobres, a higienização dos espaços públicos e o sonho de limpeza e disciplinamento das condições de vida dos mais pobres.

O projeto urbanístico de Paris no século XIX se dá numa concepção burguesa de civilização, apoiada na ordem e no progresso. Quem promove a realização desse sonho urbanístico é Georges Eugène Haussmann, prefeito de Paris:

O ideal urbanístico de Haussman era a larga perspectiva através das avenidas. Esse ideal corresponde à tendência do século XIX de enobrecer necessidades técnicas com fins artísticos. Essas avenidas eram os monumentos do poder da burguesia, temporal e espiritual.

[...] Haussman impôs a ditadura em Paris e governou em estado de exceção, exatamente como o Imperador, e, como ele, foi a encarnação do capital financeiro. Foi o urbanista do absolutismo bonapartista que criou uma cidade por decreto, e com isso aplicou a Paris a técnica do golpe de estado que levou Luís Napoleão ao poder.

[...] facilitar a movimentação de tropas das casernas aos bairros populares e dificultar a construção de barricadas pelo alargamento das ruas. O encarecimento dos aluguéis expulsa de Paris as famílias proletárias. A nova Paris foi o paraíso da especulação. A fraude era a regra [...] (Rouanet, 1992, p. 55). 
A Metrópole, símbolo do mundo moderno, e a revolução urbanística como parte do projeto político, excludente e disciplinador, são características da dinâmica burguesa, inclusive o movimento dialético, como explica Berman (2007) valendo-se de Karl Marx:

A burguesia não pode sobreviver sem revolucionar constantemente os instrumentos de produção, e com eles as relações de produção, e com eles todas as relações sociais. [...] Revolução ininterrupta da produção, contínua perturbação de todas as relações sociais, interminável incerteza e agitação, distinguem a era burguesa de todas as anteriores [...].

[...] Todas as relações fixas, enrijecidas, com seu travo de antigüidade e veneráveis preconceitos e opiniões, foram banidas; todas as novas relações se tornaram antiquadas antes que chegassem a se ossificar. Tudo o que é sólido desmancha no ar, tudo o que é sagrado é profano, e os homens finalmente são levados a enfrentar [...] as verdadeiras condições de suas vidas e suas relações com seus companheiros humanos [...] (Marx apud Berman, 2007, p. 30-31).

Em "Tudo que é sólido desmancha no ar", Berman (no capítulo III: "Baudelaire: o modernismo nas ruas") faz referência a dois poemas em prosa de Baudelaire que situam o mundo dos bulevares entre outros aspectos de Paris e a revolução urbanística burguesa: "Os Olhos dos Pobres" e "A Perda do Halo".

Berman (2007) relaciona o Halo aos valores considerados os mais sagrados. Em outras palavras, a modernização da cidade representa a realização dos desejos mais íntimos de urbanidade - pelo vínculo público e privado no mesmo lugar, realiza o desejo da burguesia pela apropriação dos espaços da cidade e vai até a alma do cidadão. A cidade Paris é transformada a partir do comando de Napoleão III e Haussmann.

Situamos os escritos de "Os olhos dos Pobres" na administração de Georges Eugène Haussmann, prefeito de Paris que, em fins dos anos 1850, sob os auspícios de Napoleão III, realiza a rede de bulevares: [...] o 
novo bulevar parisiense foi a mais espetacular inovação urbana do século XIX, decisivo ponto de partida para a modernização da cidade tradicional [...] (Berman, 2007, p. 180).

E, com essa invenção, conseguiram desarticular a rua como espaço de organização dos trabalhadores.

A mudança na paisagem significa novas formas de estabelecimento de poder e demarcação de territórios.

Os bulevares representam apenas uma parte do amplo sistema de planejamento urbano, que incluía mercados centrais, pontes, esgotos, fornecimento de água, a Ópera e outros monumentos culturais, uma grande rede de parques [...]. Os bulevares de Napoleão e Haussmann criaram novas bases - econômicas, sociais, estéticas - para reunir um enorme contingente de pessoas. No nível da rua, elas se enfileiravam em frente a pequenos negócios e lojas de todos os tipos e, em cada esquina, restaurantes com terraços e cafés nas calçadas [...] (Berman, 2007, p. 180-181).

É importante atentar, a partir das narrativas de Berman (2007), para a estética desse planejamento urbano mencionado como constituidor de desejos burgueses, realizados pelo desenvolvimento de técnicas como ruptura do espaço público relacionado às manifestações pelos pobres. Acaba por transformar a rua a partir dos bulevares em espaços "público-privados" de socialização da burguesia, pela divisão espacial, social e individual.

Assim, separam-se os sujeitos desprovidos das qualidades burguesas necessárias ao uso e ocupação do espaço, pelas rupturas como demolições, novas construções e contrastes entre riqueza e pobreza. Observa-se o espetáculo da miséria no centro. Tendo a engenharia moderna como técnica, Napoleão e Haussmann promovem a moderna Paris do século XIX.

[...] conceberam as novas vias e artérias como um sistema circulatório urbano. Tais imagens, lugar-comum hoje, eram altamente revolucionárias para a vida urbana do século XIX. Os novos bulevares permitiram ao tráfico fluir pelo centro da 
cidade e mover-se em linha reta, de um extremo a outro - um empreendimento quixotesco e virtualmente inimaginável, até então. Além disso, eles eliminaram as habitações miseráveis e abriram 'espaços livres' em meio a camadas de escuridão e apertado congestionamento. Estimulariam uma tremenda expansão de negócios locais, em todos os níveis, e ajudariam a custear imensas demolições municipais, indenizações e novas construções. Pacificariam as massas, empregando dezenas de milhares de trabalhadores - o que às vezes chegou a um quarto da mão-de-obra disponível na cidade - em obras públicas de longo prazo, as quais por sua vez gerariam milhares de novos empregos no setor privado. Por fim, criariam longos e largos corredores através dos quais as tropas de artilharia poderiam mover-se eficazmente contra futuras barricadas e insurreições populares [...] (Berman, 2007, p. 180).

O planejamento urbanístico explorou as contradições da modernidade. Foi um projeto burguês que visou mascarar os conflitos de classes, as lutas e reivindicações sociais das ruas, acalmar o povo. Tirando as multidões das ruas, procurando manter as mentes distantes e camuflando as desigualdades sociais, introduziu o modo de vida burguesa, ainda que pelo desejo de ser burguês. Em outras palavras, desenvolver uma ética de manter o povo distante e, ao mesmo tempo, alimentar um sonho "realizável" de ser burguês pelo modo de produção capitalista. O trânsito é permitido, embora vigiado, controlado. O povo poderia sonhar com a comida, mas de barriga vazia. E pelo seu próprio trabalho, em tese, poderia usufruir das mesmas benesses burguesas. A contradição está em que nem todos, ou melhor, a maioria não pode ter acesso a esses bens, só poucos, privilegiados à custa da própria exploração alheia, por sinal, burguesa. A chave para o sucesso do projeto urbanístico, donde insurge seu caráter revolucionário, é convencer que o miserável fique longe dos problemas, e também distante de sua moradia do centro, do centro de decisões burguesas, mas que alimente o desejo de possuir o modo de ser 
e de viver. Essa foi a grande lição da revolução urbanística: explorar os espaços por meio das pessoas, do sentimento e desejo individual de ser burguês. Inaugurou uma nova maneira de vida em sociedade. A Arquitetura, em especial a rodovia, no Século XX, funciona como freio à Revolução, como salienta Berman (2007, p. 200).

As implicações políticas não foram inteiramente apreendidas no momento - e não se sabe se Le Corbusier estava de todo atento a elas —, mas nós agora temos condições de compreendê-las. Tese defendida pela população urbana, a partir de 1789, ao longo de todo o século XIX e nos grandes levantes revolucionários do final da Primeira Guerra: as ruas pertencem ao povo. Antíteses, e eis a grande contribuição de Le Corbusier: nada de ruas, nada de Povo. Nas ruas da cidade pós-haussmanniana, as contribuições sociais e psíquicas fundamentais da vida moderna continuam atuantes, em permanente ameaça de erupção. Contudo, se essas ruas puderem simplesmente ser riscadas do mapa - Le Corbusier o disse, bastante claro, em 1929: 'precisamos matar a rua!' - talvez essas contradições nunca venham a nos molestar [...].

Com a modernidade e suas contradições, novas formas de relações urbanísticas, sociais, políticas e econômicas são estabelecidas, num complexo sistema em que é preciso ter a senha para entrar no mundo burguês. Já a porta da saída quase sempre está aberta. O que não se resolveu até hoje é que um belo dia a multidão não bate à porta, mas entra sem ser convidada, e isso gera pânico, medo e insegurança. Esse é o grande temor burguês: perder o que conquistou a duras penas, ou mesmo à custa da exploração do outro. A revolução urbanística não conseguiu resolver isso: a violência urbana escapa entre os dedos da burguesia como água e vinho misturados. O desejo de ter a qualquer preço, muitas vezes quando não se tem, leva o homem a usar a força, pagando com a própria vida; por isso, nesse mundo, os instrumentos burgueses não são capazes de conter a multidão só pela ideologia. Essa situação inaceitável faz parte do 
mundo burguês. À custa, muitas vezes, da brutalidade, quando os "monstros" criados pela modernidade resolvem atacar, quase sempre se pergunta pelo sentido da vida, esquece-se da teoria da ação e reação. Nesse campo, a forma artística, estética, tem dois lados, é uma dança que vai dos clássicos ao cafona. Do céu ao inferno. O grito da rua continua vivo.

É irônico que, tanto na teoria como na prática, a mistificação da vida moderna, bem como a destruição de algumas das suas mais atraentes possibilidades, tenha sido levada a termo em nome do próprio modernismo em progresso.

[...] Jane Jacobs escreveu um livro profético sobre esse novo urbanismo: Morte e Vida das Grandes Cidades Norte-americanas, publicado em 1961. O primeiro, brilhante, argumento de Jacobs é que os espaços urbanos criados pelo modernismo eram fisicamente limpos e ordenados, mas social e espiritualmente mortos; o segundo, que foram tão-só vestígios da congestão, do barulho e da dissonância geral do século XIX que mantiveram viva a vida urbana contemporânea; o terceiro, que o velho 'caos' urbano na verdade constituía uma ordem humana maravilhosamente rica e complexa, de que os modernistas não deram conta porque seus paradigmas de ordem eram mecânicos, redutivos e frívolos; por fim, que tudo o que passa por modernismo, em 1960, pode logo se tornar evanescente e obsoleto [...] (Berman, 2007, p. 202).

A modernidade, concebida como espaço de aglutinação com as tradições, especialmente no campo ideológico, mistura o antigo com o novo, já que o processo de construção humana é dialético. Nos padrões da modernidade e suas contradições, brutal violência, desigualdade e intolerância, também existe uma ordem, tanto do ponto de vista econômico, social, como político. É a ordem burguesa em formação e o incipiente capitalismo industrial e financeiro. Esses valores e tradições, "modernos" na forma, mas "antigos" em conteúdo, podem ser estabelecidos numa estética, mas adaptados às condições concretas do tempo e espaço de cada país e cultura no Ocidente. Um processo massivo, de vigilância constante do modo de vida dos trabalhadores. 
O século XX pode ser analisado sob vários olhares acerca da história, da desumanização pelas guerras e contradições entre exploradores e explorados. E como é preciso resistir e lutar, organizar-se para transformar, rever conceitos, valores e crenças, apresenta-se o socialismo como um caminho a ser seguido, ainda que, diante de tantos obstáculos, seja preciso crer num outro mundo mais humano, menos robotizado. Onde há sentimentos maiores que movem o mundo além do bem e do mal. Das verdades de poucos e das mentiras também.

Podemos observar pela paisagem aspectos da vida cotidiana, do mundo alienante, em que o trabalhador vende não só sua força de trabalho, mas a própria vida, que não tem valor algum, é apenas uma peça na imensa engrenagem do tempo e do espaço burguês. Do capital. Da solidão, do supérfluo, artificial, e também moralizante (tradicional), para não se perder o controle sobre a sociedade. E, mais, para aumentar a rigidez "moral" e exercer um melhor controle sobre a vida social dos mais pobres, não para ajudá-los, mas para oprimi-los, humilhá-los, colocá-los no seu "devido lugar". Essa é a ordem social burguesa: a tradição para controlar, a polícia para bater. A vigilância, na modernidade, usa todos os recursos, inclusive tecnológicos, para manter uma ordem a serviço dos mais ricos. Por outro lado, os usa também para aumentar seus lucros e obter melhores resultados.

Na modernidade, a paisagem se revela como constituidora de símbolos do progresso e suas contradições sociais. Como espaço de produção e reprodução de desigualdades:

A primeira coisa que observaremos será a nova paisagem, lentamente desenvolvida, diferenciada e dinâmica, na qual tem lugar a experiência moderna. Trata-se de uma paisagem de engenhos a vapor, fábricas automatizadas, ferrovias, amplas novas zonas industriais; prolíficas cidades que cresceram do dia para a noite, quase sempre com aterradoras conseqüências para o ser humano; jornais, diários, 
telégrafos, telefones e outros instrumentos de media, que se comunicam em escada cada vez maior; Estados nacionais cada vez mais fortes e conglomerados multinacionais de capital; movimentos sociais de massa, que lutam contra essas modernizações de cima para baixo, um mercado mundial que a tudo abarca, em crescente expansão, capaz de um estarrecedor desperdício e devastação, capaz de tudo exceto solidez e estabilidade [...] (Berman, 2007, p. 28).

Ao longo desse trabalho, daremos destaque à técnica como instrumento que potencializa desigualdades ao longo da história, embora sua ideia seja de melhorias, avanços para a humanidade, a partir das descobertas da ciência e de várias outras utilidades que contribuem para a qualidade de vida; por outro lado, as mesmas contradições se revelam a partir do conjunto de técnicas a serviço muito mais da burguesia do que da maioria pobre. As condições de vida na modernidade expõem suas contradições históricas, como acentua Marx (apud Berman, 2007, p. 29).

De um lado, tiveram acesso à vida forças industriais e científicas que nenhuma época anterior, na história da humanidade, chegara a suspeitar. De outro lado, estamos diante de sintomas de decadência que ultrapassam em muito os horrores dos últimos tempos do Império Romano. Em nossos dias, tudo parece estar impregnado do seu contrário. O Maquinário, dotado do maravilhoso poder de amenizar e aperfeiçoar o trabalho humano, só faz como se observa, sacrificá-lo e sobrecarregá-lo. As mais avançadas fontes de saúde, graças a uma misteriosa distorção, tornaram-se fontes de penúria. As conquistas da arte parecem ter sido conseguidas com a perda do caráter. Na mesma instância em que a humanidade domina a natureza, o homem parece escravizar-se a outros homens ou à sua própria infâmia. Até a pura luz da ciência parece incapaz de brilhar senão no escuro pano de fundo da ignorância. Todas as nossas invenções e progressos parecem dotar a vida intelectual às forças materiais, estupidificando a vida humana ao nível da força material [...]. 


\section{A utopia de civilidade em São Paulo pela importação de hábitos estrangeiros: a tradição entre o atraso e o moderno}

No Brasil, a modernidade sofria uma influência marcante do ideal de civilidade europeu; porém, com as devidas adaptações, uniria a tradição (atraso) ao urbano-moderno, este traduzido numa postura elitista que se forma dos discursos e que tem influência no ideal de ordem e progresso. O modus operandi - o positivismo, liberalismo e republicanismo -, como visto, constitui-se numa tradição por meio do discurso das elites. Unindo a "tradição antiga e o moderno", surge uma "nova tradição" de que seria preciso modernizar-se diante do atraso do Brasil rural para o moderno urbano. São, portanto, criadas condições para uma melhor manutenção e ampliação de desigualdades; saímos da escravidão da Monarquia e entramos na República, negando o nacional, e substituindo-se a mão de obra escrava pelo imigrante branco, próximo do mundo europeu. A questão social foi deixada de lado; virou, no máximo, caso de polícia, sufocando os movimentos sociais existentes. Do atraso, herdamos também a burocracia do Estado brasileiro do Império, uma perversa herança portuguesa que esconde e macula as instituições, colocando para debaixo do tapete as mazelas do país, inclusive escamoteando as fraudes eleitorais, dando legitimidade e legalidade a processos fraudulentos de eleição, como a eleição "a bico de pena"; considerando como válidos os votos de cabresto, favorecendo o analfabetismo, afastando o povo da verdade eleitoral, excluindo-o e arrancando sua força potencial.

Uma estrutura de poder reside na burocracia, de dominação da elite agrária, e também burguesa, constituindo-se numa tradição vergonhosa e autoritária. A elite utiliza tal estrutura poderosa como discurso para ganhar adeptos, inclusive os ditos liberais, mas que, na prática, querem tê-la em suas entranhas para manter privilégios, riquezas e controle social, numa espécie de "arcabouço" tecido para manipular "almas". A moderni- 
dade brasileira caminha presa ao ventre, como irmã siamesa, da tradição burocrática. Manifesta-se a burocracia no artificialismo da lei manipulada pela máquina do Estado Republicano Brasileiro a favor da elite.

Destacamos a modernidade para falar da higiene ao longo dos parágrafos anteriores devido a sua forma de lidar com a questão urbana, em especial as questões de saúde pública disseminadas por meio da ideia de "civilização". E, assim, a higiene passará por essa concepção no trato com a pobreza, como espaço de negação do que é nacional e pela importação de hábitos e costumes ditos modernos de fora.

No caso de São Paulo, a modernidade vai buscar inspiração nos modelos urbanos europeus, mas sem um planejamento urbano adequado e negando a pobreza como parte da construção da cidade; os pobres serão empurrados para as bordas do perímetro urbano.

O público e o privado numa paulicéia desvairada

A expansão urbana de São Paulo esteve vinculada diretamente aos sucessos e/ou dificuldades da economia cafeeira. Além de determinar o ritmo de crescimento da cidade, o café também definia o ritmo de vida na cidade: as épocas do ano eram as da safra, da entressafra e da colheita; o comércio era movido pelo café e sofria as conseqüências de suas cotações; a cidade, as pessoas, sua sobrevivência e até o seu temperamento e conduta dependiam drasticamente da sorte de um único produto - o 'ouro verde'.

Dessa forma, em poucos anos a capital paulista consolidouse como o grande centro capitalista, integrador regional, mercado distribuidor e receptor de produtos e serviços, fatores nitidamente vinculados ao crescimento da produção cafeeira. A política desencadeada pela cafeicultura paulista, estimulando e promovendo intensamente a imigração, em proporções bem superiores às possibilidades de emprego no campo, favoreceu muito o crescimento da população urbana. Assim, em momentos de queda do preço do café, geada ou pragas, a evasão dos colonos do campo era acentuada, provocando acúmulo de despossuídos na cidade, gerando um novo perfil populacional [...]. 
[...] Nesse processo de urbanização coexistiam permanências, demolições e construções, cresciam as obras públicas, espaços passavam a ser definidos como novas áreas comerciais e financeiras, além da zona do meretrício. Conjuntamente com a intensificação industrial, quarteirões e bairros, diferenciavam-se segundo a predominância das atividades ali estabelecidas; ruas, vilas e cortiços povoados sobretudo por operários, em sua maioria imigrantes, mostravam a latência de um espaço entre a casa e a rua onde ocorriam trocas permanentes, estabelecendo relações dinâmicas e criando laços de solidariedade [...] (Matos, 1996, p. 132).

O povo, em sua maioria, era alijado do processo político-eleitoral. No entanto, encontramos na cidade um campo político de luta pela resistência contra a exploração: ex-escravos, mestiços, migrantes e imigrantes constituindo-se em movimentos sociais de luta por melhores condições de vida e salário, a exemplo dos operários urbanos. É importante uma análise a partir de diferentes interpretações dos fatos acerca do fazer histórico e a contribuição dos diversos personagens como sujeitos que contribuíram na construção da nossa história.

Do ponto de vista do mundo moderno, podemos situar o Brasil num cenário em que temos por parte das elites hegemônicas o discurso positivista, liberal e republicano, que aposta no "progresso" (ideologia) para deixarmos de ser atrasados e nos tornarmos civilizados, inclusive por meio do embranquecimento da população.

Modernidade é um termo usado para representar o conjunto de transformações estruturais e cotidianas decorrentes do desenvolvimento da era industrial. No período compreendido entre o fim do século XIX e o início do século XX, novas fontes de energia e novas tecnologias alteraram profundamente a vida do homem, mudando seu modo de produzir, comerciar, pensar, habitar, alimentar-se, divertir-se e conduzir as relações político-sociais [...] (Janotti, 1999, p. 79). 
A sociedade passa a ser pautada na velocidade, encurtando distâncias com o aperfeiçoamento dos meios de transporte, bem como o surgimento constante de novas criações (fotografia, telégrafo, rádio); a acumulação de capital dita o ritmo do progresso. O transporte de bens (com a circulação de produtos para áreas cada vez mais distantes) e de massas emerge como símbolo do progresso por meio do trem, da agilidade e segurança da navegação marítima, deixando para trás a tração animal. O impacto se dá com a criação e difusão do automóvel, do cinema, do submarino, do avião. O homem burguês agora tem o controle do tempo e do espaço. Isso causa também uma dependência que pressupõe o capital para se ter acesso à modernidade; portanto, ela não é para todos (Janotti, 1999, p. 79-80).

No Brasil urbano, havia uma dinâmica social peculiar desde os primeiros anos da República, tanto pelo modo de vida burguês na delimitação de espaços e modificação da paisagem, construindo um ambiente urbano dos negócios ligados especialmente ao café, como também por um contraponto marcado pela atuação dos "movimentos anarquistas e anarco-sindicalistas" na luta por melhores condições de vida e trabalho, em especial no período de 1917-1920 com as greves que paralisaram São Paulo.

Nesse período emergirá o Partido Comunista Brasileiro, de cunho socialista, com influência das ideias da III Internacional Comunista, inspiradas na Revolução Russa de 1917.

Portanto, tal partido surge do choque entre esses diversos brasis, rico e pobre, rural e urbano, o que ultrapassa o simples embate entre as forças oligárquicas dissidentes, desprestigiadas pela "República" do cafécom-leite. O cerne da questão do ponto de vista interno, especialmente no ambiente urbano, é que a burguesia industrial, ligada aos setores médios urbanos desde o século XIX, não viu seu projeto industrial virar realidade; e, no novo cenário, contará com um elemento novo, que, em- 
bora em pequeno número, por suas ideologias, têm importância histórica, pois fornecia elementos para mudanças. É nesses grupos que a burguesia "se apoiará". Eram forças progressistas para a época: as classes operárias, como voz do operariado. E também das massas da sociedade urbana excluída do processo político. Havia um liberalismo excludente, no qual a lei beneficiava a poucos. A elite dominava.

Há, no entanto, opiniões diversas acerca desses grupos sociais urbanos:

O movimento da classe trabalhadora urbana no curso da Primeira República foi limitado e só excepcionalmente alcançou êxitos. As principais razões desse fato se encontram no reduzido significado da indústria, sob o aspecto econômico, e da classe operária, sob o aspecto político. As greves só tinham forte repercussão quando eram gerais ou quando atingiam setores-chave do sistema agroexportador, como as ferrovias e os portos. Por sua vez, o jogo político oligárquico podia ser feito sem necessidade de se agradar à massa operária nascente. Os operários se dividiam por rivalidades étnicas e estavam propensos a organizar-se, pois a simples sindicalização já os colocava na 'lista negra' dos industriais. Além disso, muitos deles eram imigrantes que não tinham abandonado ainda as esperanças de 'fazer a América' e voltar para a Europa [...]

[...] Em São Paulo predominou o anarquismo, ou melhor, uma versão dele: o anarco-sindicalismo, uma corrente do movimento operário que teve seu apogeu na Europa e nos Estados Unidos entre as últimas décadas do século XIX e início da Primeira Guerra Mundial. Tinha por objetivo a transformação radical da sociedade e a implantação do socialismo [...].

[...] Adversários do marxismo, eles assumiam, entretanto, ao pé da letra, a afirmação de Marx de que a emancipação dos trabalhadores cabia aos próprios trabalhadores.

Na prática, tendo em vista a distância entre seu programa e a realidade social brasileira, os anarquistas foram levados a concentrar esforços nas mesmas reivindicações sustentadas por seus adversários. Isso não impediu que as duas tendências guerreassem entre si, debilitando o já frágil movimento operário [...] (Fausto, 2006, p. 297-298). 
O modelo de racionalidade, a partir do contato de setores elitistas com o mundo europeu, vem numa perspectiva de utopia de civilização que encontrará terreno fértil e deleite nos pensamentos e desejos de setores liberais de serviços e 'progressistas' próximos da elite cafeeira. Podemos destacar a ideia de ordem e progresso positivista associada ao moderno como uma inspiração de destaque para uma concepção de vida burguesa que atenda a perspectiva de cidade, que supostamente romperá com o atraso do mundo rural, alimentada por setores liberais (bacharéis, engenheiros, médicos), mas próximos da vida na cidade e dos meios intelectualizados, especialistas em discursos de grandiosidade.

Na República, temos uma 'nova ordem' do ponto de vista político, com um liberalismo excludente, da lei, do discurso, da artificialidade, mas que, na prática, beneficia as oligarquias, os coronéis. Contava essa ordem com as novas classes médias, devido ao processo urbano e à incipiente indústria, surgindo, também, uma classe de operários, que integra inclusive grupos anarquistas. A repressão do Estado atuava no sentido de sufocálos e excluí-los do processo político e eleitoral. Ângela de Castro Gomes (2006), no artigo A Política Brasileira em busca da modernidade: na fronteira entre o público e o privado, discorre sobre o enfrentamento do dilema público/privado, cuja base se assenta na formação histórica, permeando o pensamento e o imaginário social de nações atrasadas como o Brasil. Envolveria, do ponto de vista da política moderna, repensar uma política que atendesse:

[...] o mundo dos cidadãos racionais e dos procedimentos públicos impessoais, mundo existente de fato nos países desenvolvidos. De outro lado, a necessidade de compreensão de uma realidade social que com ele se confrontava, pois fundava-se em padrões de autoridade tradicionais- personalizada e emocional-, que não podiam ser ignorados e menosprezados, sob pena de total insucesso [...] (Gomes, 2006, p. 499). 
A província de São Paulo, no segundo quartel do século XIX e início do século XX, experimenta mudanças no ambiente urbano e demográfico, somadas ao paulatino controle dos espaços públicos em associação com o privado, conforme análise de Paulo César Garcez Marins (2006) em História da Vida Privada no Brasil, sobre o tema da "Habitação e Vizinhança: Limites da Privacidade no Surgimento das Metrópoles Brasileiras".

As precárias condições sanitárias presentes nas casas dos bairros de imigrantes, juntamente com as encontradas nos cortiços espalhados por quase toda a cidade, justificaram a expansão do aparelho oficial de fiscalização higiênica, cujos resultados antecederam os que seriam alcançados no Rio de Janeiro na primeira década do século XX - não por acaso pelas mesmas elites paulistas. A remodelação do Serviço Sanitário deu-se ainda em 1892, seguida pela edição do Código Sanitário de 1894 - que proibiu novos cortiços - e as normas de 1896 e 1906, culminando o reaparelhamento dos dispositivos de fiscalização com a reforma do próprio Código em 1911, que definiu como sendo dos municípios a competência de adequação sanitária das habitações. As intenções normativas do poder público surpreenderam a cidade de São Paulo no início de sua expansão geográfica, o que possibilitou uma paulatina padronização dos espaços domésticos, disciplinando-os mediante o apanágio da "saúde pública":

Quer do ponto de vista social, quer sanitário, a higiene domiciliar merece detido exame dos poderes públicos [...]

São as casas imundas o berço do vício e do crime.

Os indivíduos que vivem na miséria e abrigados aos pares, em cubículos escuros e respirando gases mefíticos, que exalam de seus próprios corpos não asseados, perdem de uma vez os princípios da moral e atiram-se cegos ao crime e ao roubo de forma a perderem sua liberdade ou a ganharem por essa forma meios de se alimentarem ou dormirem melhor. Uma solução para as coabitações e indefinições de espaços domésticos familiares das moradias coletivas tradicionais foi a das vilas operárias ou das casas populares [...]. Ambas se expandiram em São Paulo, mediante o cumprimento das normas mínimas exigidas legalmente, espalhando-se pelos 
bairros das zonas leste e oeste da cidade, servidos pelos trens e bondes. Otimizando o controle sanitário sobre as casas construídas individualmente, as vilas ainda submeteram seus ocupantes às primeiras experiências de massificação da moradia, seja pela disposição rígida das plantas arquitetônicas em cada unidade privada seja pela própria uniformidade externa dos blocos de habitações (Marins, 2006, p. 173-175).

A partir da citação, podemos identificar o quanto estava presente a ideia de civilização associada à elite constitutiva de uma São Paulo nos moldes europeus. A higiene terá o sentido de limpar a cidade da pobreza e também de cuidar de doenças como um mal que ameaça vidas e, nesse aspecto, será explorado o discurso de que a ciência resolveria os problemas da humanidade. A crença no progresso e no ideal positivista de melhora na condição humana (como ideologias) permite as condições para as transformações econômicas, políticas e sociais do mundo urbano de São Paulo. A modernidade vai se constituir numa crença do novo homem, ordeiro, letrado, como garantia de manutenção de desigualdades e exaltação de uma elite decadente e de negação da cidadania para os pobres: negros, nacionais e imigrantes.

No cenário de São Paulo, como província, observa-se que o projeto utópico civilizatório ocorre por meio do afastamento dos pobres progressivamente em direção às periferias da cidade, num processo de separação espacial e social entre riqueza e pobreza.

A incipiência da urbanização paulistana por ocasião da República acabou por inviabilizar não só o controle mais eficiente dos bairros e habitações populares, mas o próprio zoneamento dessas áreas, em locais efetivamente distintos daqueles em que depressa se concentraram as moradias obedientes à clivagem entre espaços privados e públicos almejados pelas elites republicanas. O inchaço abrupto e insalubre sofrido por São Paulo não obstou que os setores sociais mais abastados e médios fossem agregando-se, já a partir da década de 1880, em novos e amplos bairros, pró- 
ximos entre si, que se desmanchavam no Rio de Janeiro e nas outras grandes capitais estaduais. A ausência de morros ou vales nas proximidades dos bairros planificados e providos de melhorias eximiu os palacetes e casas médias de vizinhos destoantes, como favelas ou mocambos.

Campos Elísios, porções de Santa Ifigênia e da Liberdade, e sobretudo o emblemático bairro arruado em 1893, Higienópolis, passaram a abrigar famílias abastadas ligadas aos negócios da cafeicultura. Em 1891 foi inaugurada a avenida Paulista, a qual, a partir da década seguinte, também passaria a acolher imigrantes enriquecidos ou famílias ligadas a atividades financeiras e imobiliárias que construíram amplas residências para rivalizar com os suntuosos palacetes das famílias dos "barões do café" - ou de suas poderosas viúvas ou filhas - instalados solidamente em Higienópolis e nos bairros mais centrais [...].

[...] A construção dos novos bairros residenciais elegantes adequados aos preceitos sanitários, plásticos e comportamentais gerados no cotidiano burguês das cidades européias, conseguiu forjar em São Paulo uma mancha contínua de vizinhanças homogêneas. Excluindo-se a proximidade dos menos favorecidos, desestimulando-se seu trânsito público nas ruas dos bairros de elite. Uma ampla faixa que cercou o centro paulistano de oeste a sudoeste livrou-se da interseção de bairros ou habitações populares [...] (Marins, 2006, p. 175-178).

Floresce uma incipiente cultura liberal-capitalista, alimentada pelas ideias do modo de vida importado da Europa, que identifica o elemento branco "civilizado" como o perfil ideal de homem para compor uma nova estrutura social e política. Uma "nova" ordem.

A urbanização e o crescimento populacional são vinculados à própria geografia de São Paulo (centro articulador e distribuidor de bens e serviços) e pela economia cafeeira, que encontrará na cidade o ambiente onde os "negócios" se realizarão. São Paulo cresce em população e importância por meio da "modernidade". Mas faltava a realização do projeto burguês industrial que não havia se concretizado com a República. 
Prevalecem atividades produtivas e um processo de reelaboração da própria noção de trabalho e civilidade. São Paulo desponta como cidade e metrópole do trabalho; lócus de geração e aplicação de capital no âmbito dos investimentos e na questão de melhoramentos. Local de produção. Mas não há trabalho para todos, o que gera um paradoxo social.

\section{Referências}

AMERICANO, Jorge. São Paulo Naquele Tempo (1895-1915). 2. ed. São Paulo: Carrenho; Narrativa Um; Carbono 14, 2004. 431p.

BERMAN, Marshall. Tudo que é sólido desmancha no ar: A aventura da Modernidade. Tradução Carlos Felipe Moisés e Ana Maria Ioriatti. São Paulo: Companhia das Letras, 2007. 465p.

CALDEIRA, Teresa Pires do Rio. Cidade de Muros: Crime, segregação e cidadania em São Paulo. 2. ed. São Paulo: 34; Edusp, 2003.

CHALHOUB, Sidney. Cidade Febril: Cortiços e Epidemias na Corte Imperial. São Paulo: Companhia das Letras, 2006. 250p.

FAUSTO, Boris. História do Brasil. São Paulo: EDUSP, 2006. 660 p.

GOMES, Ângela de Castro. A Política Brasileira em Busca da Modernidade. In: SCHWARCZ, Lilia Moritz. (Org.) História da Vida Privada no Brasil: Contrastes da intimidade contemporânea. São Paulo: Companhia das Letras, 2006. v. 4. 820 p.

JANOTTI, Maria de Lourdes. Sociedade e política na Primeira República. São Paulo: Atual, 1999. 132 p. (Coleção Discutindo a História do Brasil).

JAPIASSÚ, Hilton; MARCONDES, Danilo. Dicionário básico de filosofia. 5. ed. rev.e ampl. Rio de Janeiro: Zahar, 2008. 309 p.

MARINS, Paulo César Garcez. Habitação e vizinhança: limites da privacidade no surgimento das metrópoles brasileiras. In: SEVCENKO, Nicolau (Org.) História da Vida Privada no Brasil: República - da Belle Époque à Era do Rádio. São Paulo: Companhia das Letras, 2006. v. 3. 724 p.

MATOS, Maria Izilda Santos de. Na Trama Urbana: Do público, do privado e do íntimo. Projeto História, v.13, p. 129-149, jun. 1996

OLIVEIRA SOBRINHO, Afonso Soares de. A Concepção saneadora da pobreza nas políticas públicas contemporâneas (2006-2011) na Cidade de São Paulo: análise crítica do processo de disciplinamento da informalidade. 2011. Dissertação 
(Mestrado em Políticas Sociais)-Programa de Pós-Graduação em Políticas Sociais, Universidade Cruzeiro do Sul, São Paulo, 2011.

ROUANET, Sergio Paulo. É a cidade que habita os homens ou são eles que moram nela? Revista USP, n. 15, p. 49-75, set./nov. 1992. Disponível em: < http://www. usp.br/revistausp/15/05-rouanet.pdf>. Acesso em 14 nov. 2011.

SANDRONI, Paulo. Novíssimo Dicionário de Economia. São Paulo: Best Seller, 1999. 650p.

SILVA, De Plácido e. Vocabulário Jurídico. Rio de Janeiro: Forense, 1993. 513p. WILLIANS, Raymond. Palavras-Chave: um vocabulário de cultura e sociedade. Tradução Sandra Guardini Vasconcelos. São Paulo: Boitempo, 2007. 457p. 